\title{
THE ACQUISITION OF SWEAR WORDS BY STUDENTS IN CENTRAL KALIMANTAN
}

\author{
Friyanto, Ashadi \\ Applied Linguistic Department, Graduated Program, Yogyakarta State University, Indonesia \\ Colombo No. 1, Karangmalang, Yogyakarta, 55281, Indonesia \\ Corresponding Author: friyanto.2018@student.uny.ac.id/ friyantoav@gmail.com
}

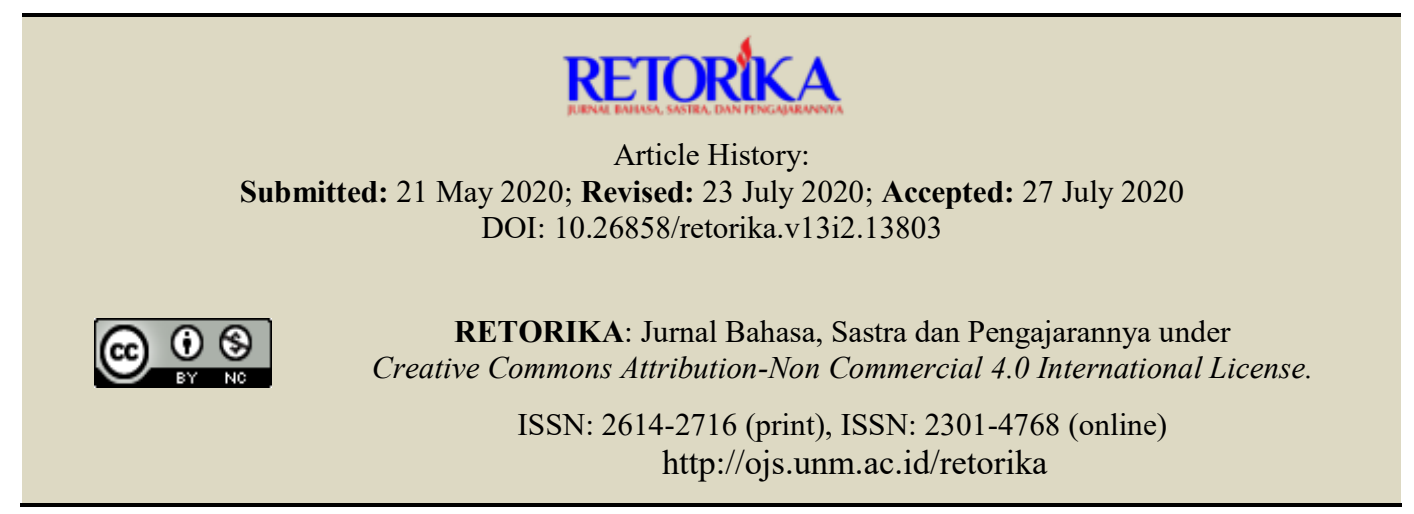

\begin{abstract}
Swear words are often associated to inappropriate expressions in all societies. This study investigates the acquisition of swear words by Indonesian students using social media which was designed in descriptive qualitative approach. Data were gathered by questionnaire and interviews method. Result shows that the students tend to use animal terms to swear to show anger to others. Further, friendship becomes the main source of their acquisition of swear words and these students tend to swear among themselves to show intimacy. Moreover, these students admitted that they learnt how to swear from social media and free videos available online.
\end{abstract}

Keywords: social media, acquisition, swear words, Indonesian students

The use of swear words in communication in society is often considered inappropriate in any situation. When people try to communicate with others, they need politeness and appropriate language as an important concept in society. Swearing in communication is not recommended because it sounds bad, impolite, and rude.

Swearing is just one way to express one's feelings toward others or something in communication. People swear in many different conditions and they believe that it is unacceptable in social life. However, many recent studies show that it can help people relieve stress, anger, and tension (Jay 2009, Ljung 2011, Stephens 2013, Wang
2013). It can be assumed that it is one of the reasons why swearing still exists in social practices nowadays.

However, the use of swear words become popular as language style to communicate among students and adults is alike. Stenstorm (1995) (as cited in Baudin and Paramasivam: 2014:14) analyzed the use of taboo words by adults and teenagers in The Bergen Corpus of London Teenager Language. It shows that teenagers use swear words more than adults. Swearing is used by children, teenagers, and adult. It isa research report of "American Demographic Magazines" showing that $72 \%$ out of 60 people in range age 18-34 years old, who stated that they like swearing in 
public place (Grimm, 2004; in Fagersten: 2005: 4; Kok, 2007:1) as cited in Wulandari (2012: 2). The phenomenon of swearing also happens in Indonesia. It is not only used by adults, but also students by various reasons to swear.

Most of Indonesian utter swear words to express their feelings. For instance, the conducted Nicolau (2016: 125) found that there are six identified emotions (pissed off, angry, surprised, annoyed, shocked, and mad) caused young learners to swear others while talking. Although, the use of swear words get a bad impact on the user.Students always use it when they need to use it. In Indonesia, the use of swear words is something inappropriate by students. However, now the use of swear words are increasing every year with new vocabulary and term. There is a regulation by Komisi Penyiaran Indonesia (KPI) to control the contents in television or movie.

The regulation is represented by the Broadcast Law article 13 which reads that the inappropriate language referring to swear words which contain insulting, vulgar words, mock the God or religion are prohibited to use in television or movie and it will be banned or sensor. The law aims to reduce negative language or inappropriate language that appears in television or movie due to it gives a bad or negative impact for audiences especially students that can be influenced too. However, now, there are other media that are more powerful than television and radio. The media are called social media. Based on the data from Kominfo (Ministry of Communication and Informatics) in 2013, internet users in Indonesia currently reach 63 million people 95 percent of which use internet to access social networks (Ayun, 2015: 2).

Social media influence students more than television and radio to use swear words; they are Facebook, Twitter, Whatapps, Instagram, and Youtube. These media are not monitored well by stakeholder and the language use are not filter well. Then, the result shows that students already knew how to use swear words because swearing is not taught in school but it is picked up from parents, peers, and media (Nicolau, 2016: 117).

Through swearing, students can express their feelings in many conditions (Baudin and Paramasivam: 2014: 14-15). They are free to swear to everyone. It makes Indonesian students now use more swear words than before. This condition is interesting due to the phenomenon of swear words among students that always develop every year. The development covers kinds of swear words due to the development of vocabulary every year and the sources to learn swear words.

The researchers conduct a research about the use of swear words by senior high school Indonesia students in East Barito regency. The main reason is the students in the present time are not hesitant to use swear words even it is inappropriate kind of language to use. Then, the study of swear words has become an important aspect of linguistics research regarding the way people behave unconsciously.

There are three consistent previous studies having swearing as the topic research. The first research was conducted by Baudin and Para-masivam (2014). They conducted the research in female students who were studying at a Malaysian secondary school in Kuala Lumpur, Malaysia. Result shows that the favorite swear words of Malaysian female teenagers are shit, damn, and hell followed by bitch, fuck, and bullshit. Then, the teenagers used swear words in negative emotions to show their anger and frustration. Further, these are also to display solidarity when making jokes and storytelling with friends. Most of them used to swear among themselves as girlfriends.

The second research was conducted by Nicolau and Sukamto (2014) in students from Binus International School, Serpong, Jakarta. Result shows that the use of swear words cannot be avoided and it becomes part of male and female language use. The students both male and female used swear words in English and Bahasa to release stress and express intense emotions. Further, male students tend to use more swear words in sexuality terms.

The third research was conducted by Amrullah (2016). Result shows that the most swear words used by the university students are fuck, bastard, shit, and god. They are used in Indonesia context because those words are often found in daily English swearing by Indonesian. Further, people who are in higher positions tend to swear more rather than people who just have no higher position.

The present study is different from previous studies as it focuses on a new variation of swear words based on Indonesian senior high school students in East Barito regency. The 
research aims to see new kinds of swear words and new source of swear words uttered by the students. The reason is to reveal the new swear words in language especially in Indonesian language. Even the study of swearing also shows similarity in term of kinds of swear words, this study tries to find out new concept or term or variation of swear words as language always develops and there are always new vocabularies that appears especially the swear words vocabularies.

Swear words have many various defi-nitions. It can be noticed that swearing is the way to show expressions. In addition, Anderson and Trudgill in Vingerhoets et al. (2013:288) and Wulandari (2017:2) define swear words as language use in which the expression: (1) refers to something taboo or stigmatized in the swearer's culture; (2) not intended to be interpreted literally; (3) can be used to express strong emotions or attitudes.

Based on the statement above, swear words are the way to express people's emotions and feelings. In addition, Kristin and Jay (2008:268) state that swearing is the use of taboo language with the purpose of expressing t speaker's emotional state.

The kinds of swear words have various types. Jay (2009:154) says that taboos in English are placed primarily on sexual references (blow job, cunt) and on those that are considered profane or blasphemous (goddamn, Jesus Christ). Taboos extend to some animal names (bitch, pig, ass), ethnic-racial-gender slurs (nigger, fag, dago), scatological referents and disgusting objects (shit, crap, douche bag), insulting references to perceived psychological, physical, or offensive slang (cluster fuck, tit run), ancestral allusions (son of a bitch, bastard), substandard vulgar terms (fart face, on the rag), and social deviations (retard, wimp, lard ass);

Furthermore, Pinker and Stapleton in Vingerhoets et al. (2013: 288) state that nowadays people may classify some varieties of swear words based on numerous taboo categories. Across the world, the most commonly used taboo categories for swearing involve bodily parts and functions, sex, and religion.

In another argument, McEnery (2006:32) says that the common swearing functions have been categorized, and it can be seen in the following model: Predicative negative adjective: 'the film is shit', Adverbial booster: 'Fucking marvelous' 'Fucking awful', Cursing expletive: 'Fuck You!/Me!/Him!/it!', Destinational usage: 'Fuck off!' 'He fucked off', Emphatic adverb/adjective: 'He fucking did it' 'In the fucking car', Figurative extension of literal meaning: 'to fuck about', General expletive: '(Oh) Fuck!', Idiomatic 'set phrase': 'fuck all' 'give a fuck', Literal usage denoting taboo referent: 'We fucked' , Imagery based on literal meaning: 'kick shit out of', Premodifying intensifying negative adjective: 'the fucking idiot', 'Pronominal' form with undefined referent: 'got shit to do', 'Reclaimed' usage - no negative intention, e.g. Niggers/ Niggaz as used by African American rappers, and Religious oaths used for emphasis: 'by God'.

Swear words can be associated with sex such as 'fuck', religion such as 'for Christ's sake', bodily functions such as 'piss', race or ethnicity such as 'white trash and negro', scatological stuff such as 'shit, death such as 'go to the hell' (Soori \& Sherafat, 2015: 67).

All previous scholars showed the term of swear words in English term. However, the term of swear words do not only exist in English language, but also exists in Indonesian language and Indonesian local language. The name of each kinds of swear words are similar to English terms, but there are several additions that put local language.

According to Wijana \& Rohmadi (2006: 119), swear words in Indonesian language can be categorized as: (1) keadaan (Condition) for instance "tolol, gila, keparat", (2) binatang (Animal) for instance "anjing, babi, bangsat", (3) makhluk halus (Ghost) for instance "setan, setan alas, tuyul", (4) benda-benda (Things) for instance "tai, tai kucing", (5) bagian tubuh (Body Parts) for instance "puki mak, cuki mai, matamu", (6) kekerabatan (Friendship) for instance "Bapakmu, nenekmu", and (7) profesi (Profession) for instance "maling, sundal, bajingan" (Triadi, 2017: 2).

From the explanation above, the concept in swear words between English and Indonesian are almost similar. The researcher will use the kind of swear words both in English and Indonesian because Indonesian students speak in some languages, such as Indonesian, local language, and English. This study aims to investigates the kind of swear words, reason to swear, media that influence to swear, and the main source of swear words. 


\section{METHOD}

The study used qualitative descriptive approach research design. Creswell (2009: 4) stated that a qualitative research is a study to investigate and understand the meaning of individual or group social problems. Data were taken from the respondents filling up a questionnaire and informal interviews with the students. Then, a questionnaire was used to collect quantitative data. Furthermore, the descriptive qualitative approach was used to explain the result from the questionnaire. Open-ended questionnaire consists of four questions to allow the participants to give their own responses. The questionnaire was adapted and modified from Nicolau \& Sukamto (2014). Then, it is divided into four sections: (1) kinds of swear words, (2) reason to swear, (3) media influencing to swear, and (4) main source to swear. Furthermore, informal interviews were also utilized to clarify responses and follow up questionnaire in order to obtain more in-depth data. The data were collected from survey within a week, since $15^{\text {th }}$ January to 2020 to $5^{\text {th }}$ February2020. The parti-cipants of the study are 14 female and male students of grade ten who were studying at a Senior High School in Barito Timur Regency, Central Borneo province, Indonesia. They are chosen by random selection and most of them are active in using social media. All of them are Indonesians and they speak Indonesian as their first language, while English is their second language.

\section{FINDINGS AND DISCUSSION}

\section{Findings}

This section presents the finding of the study about the swear words by senior high school students, reason to swear, media influenced to swear, and main source to swear.

\section{The Kinds of Swear Words}

Based on the result of data analysis, the senior high school students in Barito Timur Regency, Central Borneo province, Indonesia tend to use various kinds of swear words. Table 1 below illustrates the kinds of swear words used by them.

Table 1. The Kinds of Swear Words Used by the Students

\begin{tabular}{lcc}
\hline \multicolumn{1}{c}{ ITEM } & Frequency & \% \\
\hline Animal terms & 24 & 33.8 \\
Condition terms & 19 & 26.7 \\
Body terms & 10 & 14.3 \\
Sexual terms & 7 & 9.8 \\
Name-calling terms & 7 & 9.8 \\
Disgusting Object & 2 & 2.8 \\
Ghost terms & 1 & 1.4 \\
Blasphemous & 1 & 1.4 \\
\hline \multicolumn{1}{c}{ TOTAL } & $\mathbf{7 1}$ & $\mathbf{1 0 0}$ \\
\hline
\end{tabular}

Table 1 above shows that most of respondents used animal terms with 24 cases $(33.8 \%)$ ). The terms are Anjing, Asu, Anjrit, Anjir, Anjay, Kampret and Bangsat. The second frequency of occurrence is stupid terms with 19 cases (26.7\%) which are Bodoh, Tolol, Goblok, and Bego. Most of them are L1 (Indonesian language swear words). Animal terms stand for Anjing, Asu, Anjrit, Anjir, Anjay, Kampret and Bangsat. Meanwhile, condition terms stand for Bodoh, Tolol, Goblok, and Bego. According to Wijaya and Rohmadi (2006: 119), the word "Anjing or Asu" is one of Indonesian swear words which is called animal terms. This type always associates with name-calling in animal terms. Meanwhile, Jay (2009:154) said that people swear to someone using animal names. Further, it can be concluded that those types are animal names (for instance: pig). Besides, the words "Anjrit, Anjir, and Anjay" have the same meaning to "Anjing or Asu". These words are not found in KBBI (Kamus Besar Bahasa Indonesia) as it exists in urban dictionary and are categorized as slang word.

There is a new concept of using swear words, the combination of words in animal terms. For instance, the words "Anjrit, Anjir, and Anjay" can be related to "dog" to insult someone who has behavior like a dog based on the article in media Kompasiana.

Furthermore, the words Bodoh, Tolol, Goblok, and Bego are kinds of swear words in condition terms. Wijaya (2006: 119) said that this type 
shows something that the speaker is not favored by spoken swear words. The words Bodoh, Tolol, Goblok, and Bego or stupid in English is defined as mental state conditions. This type is used in particular conditions.

Moreover, L1 (first language) is often used to swear more than L2even though L2 (second language) is also used by the students to swear. Harris (2004:241) argued that the use of swear words in L1 is considered to be more emotional because the students are more proficient in their L1. In this case, the students use more L1 swear words rather than L2 swear words (English); such as fuck, shit, and goddamn. It happens because the students often use L1 to communicate with their friends both in School or public places. Then, the words fuck, shit and goddamn can be classified as the kinds of swear words in English (Hughes, 2006: 188, 292, 432; McEnery, 2006: 25; Jay, 2009: 154). Fairman (2006: 5) in Oliver (2011: 9) also stated that the word "fuck" can be associated as a taboo word or swearing.

Further, the ghost term refers to "tuyul" that has meaning as a subtle form that is said to be a bald-headed boy, can be ruled by people who maintain it to get money, and so on in KBBI online. The students tend to use this type in order to mock or insult someone who does not have a height or small. Meanwhile, the term i body parts are used by the students in Indonesian language such as kontol, memek, and Bangkel bangkai. Those words are sexual body parts. Kontol and dick have the same meaning and "memek" means vagina in English language. The students use body terms of swear words in communicating to their close friends and toward themselves.

Some students used animal term as that term is more applicable to use. Therefore, the use of animal terms among them are common. Meanwhile, swearing to the condition term represents their identity as a teenager who is still growing.

\section{Reason to Swear}

The students have particular main reasons in swearing among them or themselves. Therefore, by swearing the students can express their feelings. Table 2 below shows the positive and negative reasons to swear by senior high school students in Barito Timur regency.

From table 2 above, it can be seen that reasons for swearing are different. For example,
$31.4 \%$ students swear to express anger. This reason becomes the main reason to show their feeling in negative things. The second reason is joke with 6 cases $(17.3 \%)$. Among other reasons to swear, some reasons are anger and insult someone that can cause negative effect for other students. Therefore, those two expressions are negative thing. Meanwhile, the reasons in joke and happiness show close relationship among students. Furthermore, swearing represents fear, shame, frustration, and pain. The students swear to their condition.

Table 2. The Reasons to Swear

\begin{tabular}{lcc}
\hline \multicolumn{1}{c}{ ITEM } & Frequency & \% \\
\hline Anger & 11 & 31.4 \\
Joke & 6 & 17.3 \\
Pain & 5 & 14.4 \\
Happiness & 4 & 11.4 \\
Insult someone & 3 & 8.5 \\
Frustration & 3 & 8.5 \\
Fear & 2 & 5.7 \\
Shame & 1 & 2.8 \\
\hline \multicolumn{2}{c}{ TOTAL } & $\mathbf{3 5}$
\end{tabular}

The four indicators show that anger became the most dominant one among other reasons. Some of the students stated that "when I am very angry, I swear. It can help me release my intense feelings" This statement is in line with what Jay: 2009, Ljung: 2011, Stephens: 2013, Wang: 2013 found in their study. The result show that swearing can help people relieve stress, anger, and tension. It makes a lot of students swear when they express their anger through swearing both in Indonesian and English.

The next reason is for joking. This reason does not have any negative feelings. The students use swear words for joking with their close friends that really know their habit well. Some students said that "sometimes I use swear words with my friend to show the intimate of the relationship between us". This reason shows that the students use swearwords without having negative feelings or they do not insult their friends pride. It is just to have fun with and show intimate relationship. Then, in this case the swearing does not contain negative feeling or insulting someone pride. 


\section{Media Influencing to Swear}

The media refers to the social media and other media (television, film, and music) used by the students. Using social media, for instance; Facebook. Instagram, Whatsapp, Youtube, and so on, gives more influences to the students' swear words acquisition. Table 3 below shows the media that influence the students to use swear words.

\section{Table 3. Media Influencing to Swear}

The table 3 above shows that the most dominant media influencing the students are social media and Youtube's videos. As the era of technology now, it is not surprising that students

\begin{tabular}{lcc}
\hline \multicolumn{1}{c}{ ITEM } & Frequency & $\mathbf{\%}$ \\
\hline Social Media & 11 & 39.3 \\
Youtube`s Videos & 11 & 39.3 \\
Television & 4 & 14.4 \\
Music & 1 & 3.5 \\
Movie/Film & 1 & 3.5 \\
\hline \multicolumn{1}{c}{ TOTAL } & $\mathbf{2 8}$ & $\mathbf{1 0 0}$ \\
\hline
\end{tabular}

use more social media and watching Youtube's video. Those influence the students' language acquisition more effectively than other media.

\section{Tabel 3. Dominant Media Inflencing the Student}

Therefore, all students now have their smart phone and they can easily access the content of social media. Based on the interview, most of the students are rarely watched television at home in order to watch movie/film. By using smart phone, they can access many contents in social media and Youtube's videos. After the media, the next finding shows that there is a main source of swear words acquisition for students.

\section{Main Source to Swear}

The main source is to see the students acquisition of swear words. It can be derived from family or friends as the main source to swear. Table 4 shows the result of data analysis for the categorize of main source to swear.

Based on table 4 above, the main source to swear is from friends which are student's friends at school. The students know the swear words from their friends and often use swear words to their friends. It is common to see if students utter swear words with their friends in order to express their feelings, but it is inappropriate to utter swear words to family member especially in Indonesian culture.

\section{Discussion}

The acquisition of swear words by students in Barito Timur regency is related to the use of swear words by the students. (1) The students tend to use swear word in animal terms, (2) the reason to swear is to show anger to other students and themselves, (3) social media are the most media influencing the students to swear, and (4) student's friends became the main source to swear.

First, the students mostly use animal terms to swear. Further, research conducted by Putra (2013) shows that senior high school students mostly used ten types of Indonesia swear words especially animal terms in Babi and Anjing. Then, this current research also found that senior high school students use animal terms in Anjing/Asu more and the combination of Anjing/Asu is also used by them (for instance, anjay (Anjing Alay). Then, study conducted by Putra (2013) and the present study find the same kind of swear words used by senior high school students which is animal terms.

Furthermore, Fadlilatun et al (2015) conducted a research on swearing by junior and high school students. The research revealed that most of the students tend to swear in animal terms. Therefore, this current research and two previous ones show that the students use animal terms more in swearing.

Table 4. Main Source to Swear

\begin{tabular}{ccc}
\hline \multicolumn{1}{c}{ ITEM } & Frequency & \% \\
\hline Friends & 14 & 100 \\
Family & 0 & 0 \\
\hline TOTAL & $\mathbf{1 4}$ & $\mathbf{1 0 0}$ \\
\hline
\end{tabular}

Next is the reason to swear. The students have various reasons to swear. The finding shows that students mostly swear to express anger (negative feeling) and positive feeling (to shows friendship among them). In this research the student swear to show expression in anger and joke. Meanwhile, Putra's research (2013) reveals that the reason to swear is a form of expression of anger/annoyance. Further, Nicolau and Sukamto 
(2014) revealed that students mostly swear in anger expression, desire to make a point, pain, and excitement. Furthermore, Baudin and Paramasivam (2015) also revealed that the main reason of students in Malaysia to swear is to show anger expression and joke. Therefore, it is similar to the previous studies that the reason to swear is to show anger and friendship.

Next is in the media influencing the students to swear. The finding shows that social media (Facebook, Instragram, and Whatsapp) and Youtube's videos become the media influencing students to swear than other media due to the rapid change of digital era. Based on the observation with all students, the students stated that they often access social media and Youtube's videos rather than watching television, movie/ film and listen to music. All-female students said that they know some swear words both Indo-nesian or English from updated status of someone who posted on his/her social media and they also admit that watching Youtube's videos show them how to swear. Meanwhile, all male students stated that they know the form of swear words from watching game video and rap music on Youtube. They said that gamer in Youtube used many swear words in the video. Further, rap music nowadays also use many swear words for the lyrics.

The social media have impacts on female students in the use of swear words. Those influence the female students to use swear words in their real life while communicating with others. A research conducted by Triadi (2017) shows a relationship between the use of social media and swear words. Then, the result shows that social media is the place to use swear words..

Based on the responses of female and male students, social media and Youtube's video seem to be the most dominant influence to the students. This finding gives the new source of acquisition of swear words. A research by Nicolau and Sukamto (2014) showed that television and movie or film as the main source of acquisition of swear words. In teh present study, the social media (Facebook, Instragram, and Whatsapp) and Youtube become the new dominant source of acquisition of swear words.

The last discussion is in the main source to swear. The finding indicates that friendship becomes the only main source to use swear words. The students use swear words just in com-municating with their friends.
The students stated that they never gain swear words from their family due to swear words are bad language or inappropriate language to use or teach to their children. Then, research conducted by Simpson et al (2016) shows that children gain more swear words from their family especially their mother. Meanwhile, that finding does not have relationship with the students' case in senior high school in Barito Timur Regency. Therefore, the students gain and use more swear words among their friends and not their family at home.

The students stated that they commonly use swear words with their friends both at school or outside the school. The reason to swear with others are various. When their friends use swear words to them, those add their vocabulary. However, the reason can be shown anger or another expression to show student's friendship. Therefore, those two reasons make the students dared to utter swear words on the school with their friends (Rahmawati: 2013).

The students know that swear words are bad words. However, they use it in normal conversation as a means to express feelings and emotions. The students also feel that the use of swear words is fine due to they use swear words only among themselves and not with parents and teachers (as cited Baudin and Paramasivam, 2015:19). That also happens to Indonesian students, as they gain and use swear words from their friends.

Furthermore, the implication of student's swearing for language education deals with how the teachers at school can improve student's polite language through language learning. Therefore, the students must gain language learning in appropriate language or formal language to cover their knowledge about inappropriate language or informal especially swear words. Therefore, this study can be a reference for teachers at school. Furthermore, this topic can be analyzed deeper in relationship between the use of swear words by students and the role of teachers to respond that phenomenon.

\section{CONCLUSION}

The kinds of swear words found shows that the students tend to use animal terms to show their emotions which has big impact toward others. Then, the condition terms is used to express their 
feeling in bad condition toward themselves. Moreover, the main reason to swear is to show anger toward others and themselves and to show close relationship or intimacy among them. The media influencing the students to swear are social media such as Facebook, Whatsapp, Instagram and videos on Youtube. Then, the students gain and use swear words also toward their friends at school or outside the school.

Furthermore, this research shows that the students use more swear words among them. Then, this research can be considered as a reference for teachers and parents to see the students' informal language use among them. Therefore, the language learning at school must give more attention on formal or appropriate language learning. Moreover, teachers and pa-

\section{REFERENCES}

Amrullah, L. (2016). English Swear Words by Indonesian Learners. JELTL (Journal of English Language Teaching and Linguistics), 1(1): 1-12.

Ayun, P. Q. (2015). Fenomena Remaja Menggunakan Media Sosial dalam Membentuk Identitas. CHANNEL Journal, 3(2): 1-16.

Baudin, N. \& Paramasivam. S. (2014). Swearing in English among a Group of Female Malaysian Teenagers. International Journal of Contemporary Applied Sciences, 1(3): 14-25.

Creswell, J. W. (2009). Research Design: Qualitative, Quantitative, and Mixed Methods Approaches $\left(3^{r d} E d\right)$. New Delhi: Sage Publications.

Fadlilatun, R. et al. (2015). Penggunaan Makian Oleh Siswa SMP dan SMA di Kecamatan Ledo Kabupaten Bengkayang. Jurnal Pendidikan dan Pembelajaran Khatulistiwa, 4 (12): 113.Retrieved from http://jurnal.untan.ac.id/ index.php/jpdpb/article/view/12866

Fairman, C. M. (2006). Fuck. Accessed 21 $1^{\text {st }}$ June, 2020. Retrieved from http://ssrn.com/abs tract $=896790$.

Harris, C .L. (2004). Bilingual Speakers in the Lab: Psychophysiological Measures of Emotional Reactivity. Journal of Multilingual and Multicultural Development, 25(2-3): 223-247.

Hughes, G. (2006). An Encyclopedia of Swearing. New York: M.E.Sharpe.

Jay, T. (2009). The Utility and Ubiquity of Taboo Words. Perspectives on Psychological Science, 4(2): 153-161.

KBBI. Accessed 21 $1^{\text {st }}$ June, (2020). Retrieved from (https://kbbi.kemdikbud.go.id/entri/Tuyul) rents can give the students a deep understanding about the negative effect in using swearing at school and society so that they know how to communicate with others in appropriate language.

In this research, the researcher has not explored all swear words both in Indonesian and English. The swear words occur in this research are just several swear words uttered by students. However, the result of this study can also be used by the next researchers interested in the same topic to conduct further study. Thus, future researchers are suggested to investigate swearing students for further insights and swearing expressions occurring in a real-life situation not only in school.

Kompasiana.com. 22 ${ }^{\text {nd }}$ March, (2014). Mahasiswa dan Anjir. Accessed $21^{\text {st }}$ June, 2020. Retrieved from https://www.kompasiana.com/katpar/54f7fe11a33311f2608b486f/mahasiswadan-anjir.

Kristin, J., \& Jay, T. 2008. The Pragmatics of Swearing. Journal of Politeness Research, 4, $267-$ 288.

Ljung, M. (2011). Swearing: A Cross-cultural Linguistic Study. New York: Palgrave Macmillan.

McEnery, T. (2006). Swearing in English. Bad Language, Purity and Power from 1586 to the Present. New York: Routledge.

Nicolau, M. F. S. \& Sukamto, K.E. (2014). Male and Female Attitudes towards Swear Words: A Case Study at Binus International School, Kata Journal, 20 (1): 71-76.

Nicolau, M. F. S. (2016). Swear Words Among Young Learners: A Case Study of the Elementary Students. Indonesian Journal of English Language Teaching, 11(2): 117-132.

Oliver, F. E. (2011). Swearing and How to Deal with it in the Classroom. Thesis. Faculty of Education. Islandia: University of Iceland.

Putra, R. R. (2013). Bentuk dan Fungsi Kata Umpatan pada Komunikasi Informal di Kalangan Siswa SMA Negeri 3 Surabaya: Kajian Sosiolinguistik. Skriptorium, 1(3):93-105. Retrived from http://journal.unair.ac.id/SKRIP@,bentu k-danfungsi-kata-umpatan-article-6725-media -45category-8.html

Rahmawati, D. (2013). The Use of Swear Words By Junior High School Students 1 At Kotabaru Karawang West Java. Journal Thesis. English 
Department, The Faculty of Humanities, Diponegoro University, Semarang.

Simpson, et al. (2016). When Moms Say Bad Words: Family and Peer Influence on the Frequency of Swearing.Undergraduate Research Journal (IRJ), 8(2): 1-7.

Soori, A. \& Sherafat, Z. (2015). Iranian EFL Learners' Perception of English Taboo Words. Department of Language and Literature, Larestan Branch Islamic Azad University, Larestan, Iran.

Stenstrom, A.B. (1995). Taboos in Teenage Talk. In G. Melchers and B. Warren (Eds.). Studies in Anglistics (pp.71-79). Stockholm: Almqvist and Wiksell International.

Stephens, R. (2013). Swearing - the Language of Life and Death. The Psychologist, 26(9): 650- 653.

Triadi, R.B. (2017). Penggunaan Makian Bahasa Indonesia pada Media Sosial (Kajian Sosiolinguisik). Jurnal Sasindo Unpam, 5(2): 1-26
Vingerhoets, J.J.M., Bylsma, L.M., \& de Vlam, C. (2013). Swearing: A Biopyschosocial Pers-pective. Department of Medical and Clinical Psychology, Tilburg University, Tilburg - The Netherlands.

Wang, N. (2013). An Analysis of the Pragmatic Functions of "Swearing" in Interpersonal Talk. Griffith Working Papers in Pragmatics and Intercultural Communications, 71-79.

Wijana, I. D.P. \& Rohmadi, M. (2006). Sosio-linguistik: Kajian Teori dan Analisis. Yogya-karta: Pustaka Pelajar.

Wulandari, R.A. (2012). A Sociolinguistics Analysis of Swearing in From Paris with Love Movie. Thesis. Yogyakarta: English Education Department, Faculty of Languages and Arts, Yogyakarta State University.

Wulandari, O. (2017). The Use of Swear Words in Pewdiepie'S Youtube Videos. ELITE (English and Literature Journal), 4(2): 1-24. 